\title{
Failure Rate, Marginal Bone Loss, and Pink Esthetic with Socket-Shield Technique for Immediate Dental Implant Placement in the Esthetic Zone. A Systematic Review and Meta-Analysis
}

\author{
Pilar Velasco Bohórquez ${ }^{1}$, Roberta Rucco ${ }^{1}$, Álvaro Zubizarreta-Macho ${ }^{1,2, *}$, José María Montiel-Company ${ }^{3}$, \\ Susana de la Vega Buró ${ }^{1}$, Esther Cáceres Madroño ${ }^{1}$, Lara San Hipólito Marín ${ }^{1}$ and Sofía Hernández Montero ${ }^{1}$ \\ Citation: Velasco Bohórquez, P.; \\ 1 Department of Implant Surgery, Faculty of Health Sciences, Alfonso X el Sabio University, \\ 28691 Madrid, Spain; mvelaboh@uax.es (P.V.B.); rrucc@myuax.com (R.R.); sdelabur@uax.es (S.d.1.V.B.); \\ ecacemad@uax.es (E.C.M.); 1sanhmar@uax.es (L.S.H.M.); shernmon@uax.es (S.H.M.) \\ 2 Department of Surgery, Faculty of Medicine and Dentistry, University of Salamanca, 37008 Salamanca, Spain \\ 3 Department of Stomatology, Faculty of Medicine and Dentistry, University of Valencia, 46010 Valencia, Spain; \\ jose.maria.montiel@uv.es \\ * Correspondence: amacho@uax.es
} Rucco, R.; Zubizarreta-Macho, Á.; Montiel-Company, J.M.; de la Vega Buró, S.; Madroño, E.C.; Marín, L.S.H.; Hernández Montero, S. Failure Rate, Marginal Bone Loss, and Pink Esthetic with Socket-Shield Technique for Immediate Dental Implant Placement in the Esthetic Zone. A Systematic Review and Meta-Analysis. Biology 2021, 10, 549. https://doi.org/10.3390/ biology10060549

Academic Editors:

Alireza Dolatshahi-Pirouz, Stefania Cantore, Lucio Quagliuolo and Mariarosaria Boccellino

Received: 26 May 2021

Accepted: 17 June 2021

Published: 18 June 2021

Publisher's Note: MDPI stays neutral with regard to jurisdictional claims in published maps and institutional affiliations.

Copyright: (c) 2021 by the authors. Licensee MDPI, Basel, Switzerland. This article is an open access article distributed under the terms and conditions of the Creative Commons Attribution (CC BY) license (https:/ / creativecommons.org/licenses/by/ $4.0 /)$.
Simple Summary: The socket-shield technique has been proposed for preserving the bone ridge and surrounding soft tissues with immediate implantation in the extraction socket, maintaining the buccal wall fragment of the dental root. However, the socket-shield technique has not been compared with the conventional technique for immediate dental implant placement in the esthetic zone regarding the failure rate, marginal bone loss, and pink esthetic. Therefore, it is necessary to develop a systematic review and meta-analysis that provides evidence associated with the prognosis when using the socket-shield technique compared to the conventional technique.

Abstract: Aim: To compare the failure rate, marginal bone loss, and pink esthetic for the socketshield technique and the conventional technique for immediate dental implant placement in the esthetic zone. Material and methods: A systematic literature review and meta-analysis, based on the Preferred Reporting Items for Systematic Reviews and Meta-Analyses (PRISMA) recommendations, of clinical studies that evaluated the failure rate, marginal bone loss, and pink esthetic with the socketshield technique for immediate dental implant placement in the esthetic zone was performed. A total of 4 databases were consulted in the literature search: PubMed-MEDLINE, Scopus, Embase, and Web of Science. After eliminating duplicated articles and applying the inclusion criteria, 16 articles were selected for the qualitative and quantitative analysis. Results: Four randomized controlled trials, five prospective clinical studies, four retrospective studies, and three case series were included in the meta-analysis. The dental implant failure rate for the socket-shield technique for immediate dental implant placement was $1.37 \%$ (95\% CI, $0.21-2.54 \%$ ); however, no statistically significant differences between the conventional and socket-shield technique were found. The estimated mean difference in the marginal bone loss for the socket-shield technique was $-0.5 \mathrm{~mm}(95 \% \mathrm{CI},-0.82$ to -0.18$)$ and statistically significant $(p<0.01)$, with a high heterogeneity $\left(\mathrm{I}^{2}=99 \%\right)$. The mean pink esthetic score was 12.27 (Q test $=4.47 ; p$-value $\left.=0.61 ; \mathrm{I}^{2}=0 \%\right)$. The difference in pink esthetic between the conventional $(n=55)$ and socket-shield techniques $(n=55)$ for immediate dental implant placement was 1.15 (95\% CI, 0.73-1.58; Q test $=8.88 ; p$ value $\left.=0.11 ; \mathrm{I}^{2}=44 \%\right)$. The follow-up time was found to be significant (beta coefficient $=0.023 ; \mathrm{R}^{2}=85.6 \%$; $\mathrm{QM}=3.82 ; p=0.049$ ) for the PES for the socketshield technique. Conclusions: Within the limitations of this systematic review with meta-analysis, the dental implant failure rate did not differ between the socket-shield technique and conventional technique for immediate implant placement in the esthetic zone. However, a lower marginal bone loss and higher pink esthetic scores were found for the socket-shield technique compared to the conventional technique. 
Keywords: socket shield; immediate implant; pink esthetic; implant failure; marginal bone loss

\section{Introduction}

Dental extractions can cause volumetric changes in bone tissues characterized by the resorption of alveolar bone, especially the buccal bone wall, with a consequent retraction of the related soft tissues. Additionally, multiple-tooth extractions can lead to the loss of the dental papilla [1,2]. Biological mechanisms involved in the healing of the periodontal tissues after tooth extraction can cause the loss of the periodontal ligament and its vascular support [3,4]. The aforementioned physiological process can lead to esthetic problems that are difficult to resolve by methods of restoration that are able to preserve the emergence profile, especially in the anterior region. Therefore, preserving and maintaining the bone anatomy and soft tissue architecture in the anterior region is essential for maintaining esthetics in implant-supported restorations [5]. Different techniques and materials have been proposed to prevent the bone resorption; however, immediate dental implant placement and alveolar preservation procedures have been recommended [6]. Osseointegration has been defined as a direct and functional connection between bone and an artificial implant. Both the macroscopic and microscopic characteristics of dental implants could influence the success of these procedures [7]. Unfortunately, the abovementioned regenerative approaches cannot prevent the esthetic implications of physiological bone resorption or the physiological consequences of the reduced vascular supply after tooth extraction $[2,8]$. Therefore, the socket-shield technique was proposed for preserving the bone ridge and surrounding soft tissues, with immediate implantation in the extraction socket, maintaining the buccal wall fragment of the dental root [3,5]. The periodontal ligament and associated blood vessels avoid the initiation of buccal osteoclastic activity, and bone resorption and the contraction of surrounding soft tissues are prevented [5,9]. The socket-shield technique has shown a success rate of $96.5 \%$ [2]; however, teeth affected by periodontal disease, vertical or horizontal root fractures under the bone ridge, and internal root resorption can influence the prognosis after the placement of the dental implant and require further research [5]. In addition, the following clinical complications have been associated with the socket-shield technique: a lack of osteointegration of the dental implant, infections, and the mobilization, migration, and resorption of the root fragment [6]. An acceptable pink esthetic around the dental implant is generally demanded by the patient. The pink esthetic score (PES) is an index used to evaluate the soft tissue characteristics around single-tooth implant crowns. It takes into account the soft tissue level, soft tissue contour, alveolar process deficiency, soft tissue color, and texture. The maximum achievable PES is 14 , with a 0-1-2 scoring system; 0 is the lowest and 2 is the highest value [10].

The aim of this systematic review with meta-analysis was to analyze the failure rate, marginal bone loss, and pink esthetic with the socket-shield technique compared to those with the conventional technique for immediate dental implant placement in the esthetic zone. The null hypothesis $\left(\mathrm{H}_{0}\right)$ was that there would be no difference in the dental implant failure rate, marginal bone loss, and pink esthetic between the two techniques.

\section{Materials and Methods}

\subsection{Study Design}

A bibliographic search was conducted following the PRISMA (Preferred Reporting Items for Systemic Reviews and Meta-Analyses http:/ / www.prisma-statement.org (accessed on 15 April 2020)) guidelines for systematic reviews and meta-analyses (INSPLAY registration number: INPLASY202110058). The review also fulfilled the PRISMA 2009 Checklist [11]. 


\subsection{Question of Interest}

The PICO (population, intervention, comparison, and outcome) question was 'Whatis the dental implant failure rate, marginal bone loss, and pink esthetic of socket-shield technique for dental immediate implant placement compared to conventional dental immediate placement in the esthetic zone?' with the following components: populationpatients treated with the socket-shield technique for immediate dental implant placement; intervention-socket-shield technique for immediate dental implant placement in the esthetic zone; comparison-conventional immediate dental implant placement in the esthetic zone; and outcome- the dental implant failure rate, marginal bone loss, and pink esthetic.

\subsection{Databases and Search Strategy}

An electronic search was conducted in the following databases: PubMed, Scopus, Embase, Web of Sciences, and OpenGrey (www.opengrey.eu, accessed on 15 April 2020). The search covered all the literature published internationally up to July 2020. The search included fifteen medical subject heading (MeSH) terms: 'socket shield technique'; 'root membrane'; 'ridge preservation'; 'tooth socket'; 'tooth extraction'; 'tooth root'; 'partial extraction therapy'; 'anterior implant'; 'immediate implant'; 'immediate dental implant loading'; 'dental implants'; 'single-tooth'; 'dental implantation'; 'endosseous'; and 'aesthetic area implant'. The Boolean operators applied were 'OR' and 'AND'. The search terms were structured as follows: ("socket-shield technique") OR ("root-membrane") OR ("ridge preservation") OR ("tooth Socket") OR ("tooth Extraction") OR ("tooth Root") OR ("partial extraction therapy") AND ("anterior implant") AND ("immediate implant") OR ("immediate Dental Implant Loading") OR ("dental Implants, Single-Tooth") OR ("dental Implantation"), ("endosseous") OR ("esthetic area implant"). Two researchers (R.R. and Á.Z.-M.) conducted the database searches in duplicate independently.

\subsection{Study Selection}

Titles and abstracts were selected with two authors applying inclusion and exclusion criteria (Á.Z.-M. and J.M.M.-C.).

One researcher (R.R.) extracted data for the relevant variables. The systematic review was carried out (S.T.G.) and subsequent meta-analysis was performed by two researchers not involved in the selection process (Á.Z.-M. and J.M.M.-C.).

Inclusion criteria: studies recorded in databases as prospective randomized clinical trials (RCTs), retrospective studies, and case series from three patients. The review was not restricted to only RCTs due to the paucity of studies with such an experimental design and with external validity, but also to provide a complete picture of the topic. Studies that analyzed clinical and/or radiographic marginal bone loss, implant failure rates, soft tissue results, and pink esthetic scores after immediate dental implant placement in the esthetic zone using the socket-shield technique were included. Studies with samples of patients aged 18 years old or over, patients treated with the socket-shield technique for immediate dental implant placement in the esthetic zone, and follow-up periods of at least 3 months were included. No restriction was placed on the year of publication or language.

Exclusion criteria: systematic literature reviews, clinical cases, case series up to three patients and editorials; studies including patients under the age of 18 years old; studies with samples of three or fewer patients.

\subsection{Data Extraction and Study Outcomes}

The following data were extracted from each article: the author and year of publication, study type, sample size, follow-up in months, marginal bone loss, implant failures, soft tissue results, and pink esthetic scores. Data were extracted in duplicate (R.R. and S.H.M.) using predefined Excel spreadsheets. 


\subsection{Methodological Quality Assessment}

The risk of bias in the studies selected for review was assessed two authors (Á.Z.-M. and J.M.M.-C.) using the Jadad scale for assessing the methodological quality of clinical trials. The Jadad scale consists of five items that evaluate the randomization, researcher and patient blinding, and description of losses during follow-up, producing scores of $0-5$; scores less than 3 are considered indicative of low quality [12]. The level of agreement between evaluators was determined using Kappa scores.

\subsection{Quantitative Synthesis-Meta-Analysis}

The statistical data collection and analysis were conducted by two authors (Á.Z.-M. and J.M.M.-C.). The studies included for the meta-analysis were combined using a randomeffects model with various methods according to the estimated effect size. The inversevariance method was used to estimate the root apex location success rate, the MantelHaenszel method for the odds ratio (OR), and the inverse-variance method for the mean difference. For all the estimated variables, the $95 \%$ confidence intervals were calculated. The heterogeneity between the combined studies was assessed using the $Q$ test ( $p$-value $<0.05$ ) and quantified with the $\mathrm{I}^{2}$, considering slight heterogeneity if it was $25-50 \%$, moderate if $50-75 \%$, and high if $>75 \%$. Statistical significance was tested for using the $Z$ test ( $p$-value $<0.05)$. The meta-analyses are represented with forest plots. The publication bias was assessed using the trim and fill adjustment method, and is represented with Funnel plots. The R software was employed for the meta-evidence analysis.

\section{Results}

\subsection{Flow Diagram}

The initial electronic search was performed in June of 2020: 21 articles in PubMed, 31 in Web of Sciences, 17 in Embase, 10 in Scopus, and two in gray literature were identified. Of the total of 81 studies, 14 were discarded due to being duplicates. After screening the titles and abstracts, a further 26 were eliminated, leaving a total of 41 . A further 13 were rejected, as they failed to fulfil the following inclusion criteria: including survival rate data, including pink esthetic data, and presenting a minimum follow-up time of 3 months. A final total of 16 articles were included in the qualitative and quantitative synthesis, as these included all the data and variables required (Figure 1).

\subsection{Qualitative Analysis}

Of the 16 articles included, 4 were randomized clinical trials $[4,6,13,14], 5$ were prospective clinical trials [15-19], 4 were retrospective studies $[2,7,20,21]$, and 3 were case series $[8,22,23]$. In addition, 6 articles compared the outcomes of conventional immediate dental implant placement versus such placement using the socket-shield technique $[4,6,12-15]$. The sample sizes of the studies selected in the present meta-analysis range from 4 in the study by Nguyen et al., 2019 [8] to the high figure of 250 in Siormpas study, 2018 [2], with the subject ages ranging from 18 [2] to 87 [8] years, and the follow-up times from 3 [21] to 120 [2] months. The results are presented in Table 1.

\subsection{Quality Assessment}

The results of the methodological quality assessment using the Jadad scale are shown in Table 2. The Jadad scale was "Not applicable" to seven articles because they were retrospective studies $[2,7,19,20]$ and a case series $[8,21,22]$, and the authors of these articles were not blinded, nor were the studies randomized. Some randomization and blind procedures were "Not available" and, hence, the corresponding studies were not assigned scores. Two articles $[4,12]$ received scores of 4 , indicating high methodological quality. Again, the quality was most frequently compromised by failure to fulfil criteria related to the subject, treatment, language, or measurement blinding. 


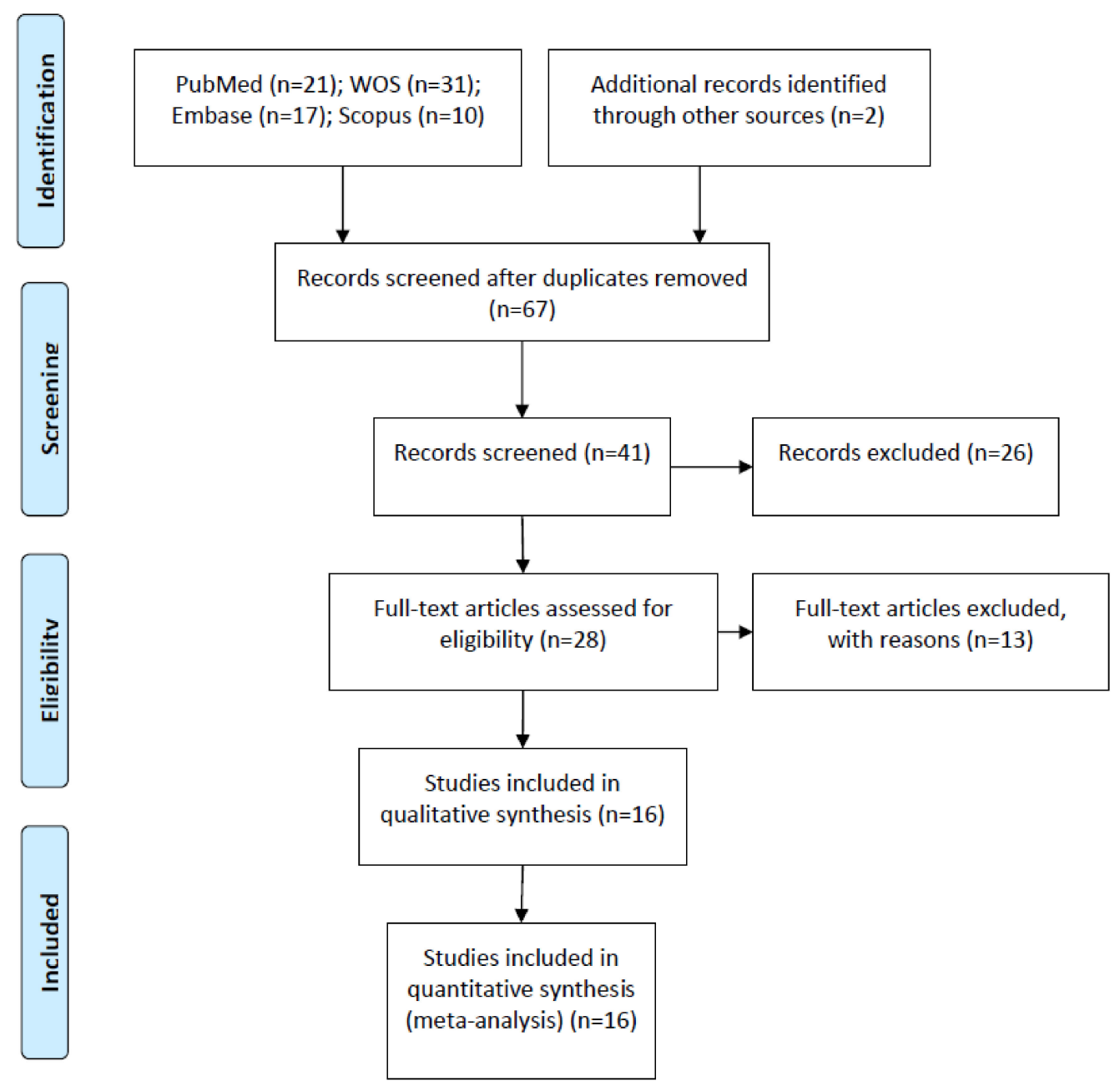

Figure 1. Preferred Reporting Items for Systematic Reviews and Meta-Analyses (PRISMA) flow diagram.

Table 1. Assessment of methodological quality according to the Jadad scale.

\begin{tabular}{|c|c|c|c|c|c|c|}
\hline \multicolumn{7}{|c|}{ Jadad Criteria } \\
\hline Author/Year & $\begin{array}{l}\text { Is the Study } \\
\text { Described as } \\
\text { Randomized? }\end{array}$ & $\begin{array}{l}\text { Is the Study } \\
\text { Described as } \\
\text { Double- } \\
\text { Blinded? }\end{array}$ & $\begin{array}{l}\text { Was There a } \\
\text { Description of } \\
\text { Withdrawals and } \\
\text { Dropouts? }\end{array}$ & $\begin{array}{l}\text { Was the Method } \\
\text { of } \\
\text { Randomization } \\
\text { Adequate? }\end{array}$ & $\begin{array}{l}\text { Was the Method } \\
\text { of Blinding } \\
\text { Appropriate? }\end{array}$ & Score \\
\hline Abadzhiev et al., 2014 [15] & 0 & 0 & 0 & 0 & 0 & 0 \\
\hline Barakat et al., 2017 [6] & 1 & 0 & 0 & NAv & 0 & 1 \\
\hline Baumer et al., 2017 [19] & NA & NA & NA & NA & NA & NA \\
\hline Bramanti et al., 2018 [4] & 1 & 1 & 0 & 1 & 1 & 4 \\
\hline Gluckman et al., 2018 [20] & NA & NA & NA & NA & NA & NA \\
\hline Habasneh et al., 2019 [22] & NA & NA & NA & NA & NA & NA \\
\hline Han et al., 2018 [5] & 0 & 0 & 0 & 0 & 0 & 0 \\
\hline Hinze et al., 2018 [21] & NA & NA & NA & NA & NA & NA \\
\hline Kher et al., 2018 [18] & 0 & 0 & 0 & 0 & 0 & 0 \\
\hline Mitsias et al., 2020 [16] & 0 & 0 & 0 & 0 & 0 & 0 \\
\hline Nguyen et al., 2019 [8] & NA & NA & NA & NA & NA & NA \\
\hline Siormpas et al., 2014 [7] & NA & NA & NA & NA & NA & NA \\
\hline Siormpas et al., 2018 [2] & NA & NA & NA & NA & NA & NA \\
\hline Sun et al., 2020 [12] & 1 & 1 & 0 & 1 & 1 & 4 \\
\hline Tiwari et al., 2019 [13] & 1 & 0 & 0 & $\mathrm{Nav}$ & 0 & 1 \\
\hline Xu et al., 2019 [14] & NAv & NAv & NAv & NAv & NAv & NAv \\
\hline
\end{tabular}


Table 2. Qualitative analysis of articles included in the systematic review.

\begin{tabular}{|c|c|c|c|c|c|c|}
\hline Author/Year & Study Type & Sample $(n)$ & $\begin{array}{c}\text { Follow-Up } \\
\text { Time (Months) }\end{array}$ & $\begin{array}{l}\text { Dental Implant } \\
\text { Failure Rate }\end{array}$ & Marginal Bone Loss & $\begin{array}{l}\text { Soft Tissue Results and } \\
\text { Pink Esthetic }\end{array}$ \\
\hline Abadzhiev et al., 2014 [15] & Prospective clinical trial & $\begin{array}{c}26 \text { dental implants } \\
\text { (25 patients } 20-64 \text { years old) }\end{array}$ & 24 & $\begin{array}{l}0 / 16 \text { CIIP } \\
0 / 10 \text { SST }\end{array}$ & $\begin{array}{l}\text { CIIP: } 12 \% \text { bone loss }(5 \mathrm{~mm}) \\
\text { SST: } 2 \% \text { bone loss }(0.8 \mathrm{~mm})\end{array}$ & $\begin{array}{c}\text { CIIP: } 12 \% \text { attached } \\
\text { gingiva loss }(5 \mathrm{~mm}) \\
\text { SST: } 2 \% \text { attached gingiva } \\
\text { loss }(0.8 \mathrm{~mm})\end{array}$ \\
\hline Barakat et al., 2017 [6] & $\mathrm{RCT}$ & $\begin{array}{l}20 \text { dental implants ( } 20 \text { patients } \\
20-50 \text { years old) }\end{array}$ & 7 & $\begin{array}{l}0 / 10 \text { CIIP } \\
0 / 10 \text { SST }\end{array}$ & $\begin{array}{l}\text { CIIP: } 1.61 \pm 0.78 \mathrm{~mm} \\
\text { vertical bone loss } \\
\text { SST: } 0.44 \pm 0.24 \mathrm{~mm} \\
\text { vertical bone loss }\end{array}$ & $\begin{array}{l}\text { CIIP: } 2.12 \pm 0.64 \mathrm{~mm} \\
\text { probing depth } \\
\text { SST: } 1.73 \pm 0.28 \mathrm{~mm} \\
\text { probing depth }\end{array}$ \\
\hline Baumer et al., 2017 [19] & Retrospective study & $\begin{array}{l}10 \text { dental implants } \\
\text { (10 patients) }\end{array}$ & $51-63$ & 0/10 SST & $\begin{array}{c}0.33 \pm 0.43 \mathrm{~mm} \text { mesial and } \\
0.17 \pm 0.36 \mathrm{~mm} \text { distal } \\
\text { marginal bone loss }\end{array}$ & $\begin{array}{l}\text { SST: }-0.37 \pm 0.18 \mathrm{~mm} \\
\text { loss of buccal tissue and } \\
-0.33 \pm 0.23 \mathrm{~mm} \\
\text { mid-facial recession } \\
\text { Pink aesthetic score: } 12\end{array}$ \\
\hline Bramanti et al., 2018 [4] & $\mathrm{RCT}$ & $\begin{array}{l}40 \text { dental implants } \\
\text { (40 patients) }\end{array}$ & 36 & $\begin{array}{l}0 / 20 \text { CIIP } \\
0 / 20 \text { SST }\end{array}$ & $\begin{array}{l}\text { CIIP: } 1.11 \pm 0.13 \mathrm{~mm} \\
\text { marginal bone loss } \\
\text { SST: } 0.60 \pm 0.06 \mathrm{~mm} \\
\text { marginal bone loss }\end{array}$ & $\begin{array}{c}\text { CIIP: Pink aesthetic } \\
\text { score: } 10.30 \pm 2.53 \\
\text { SST: Pink aesthetic score: } \\
12.15 \pm 0.76\end{array}$ \\
\hline Habasneh et al., 2019 [22] & Case series & $\begin{array}{c}5 \text { dental implants ( } 5 \text { patients } \\
20-54 \text { years old) }\end{array}$ & 12 & 0/5 SST & $\mathrm{NAv}$ & $\mathrm{NAv}$ \\
\hline Han et al., 2018 [5] & Prospective clinical trial & $\begin{array}{l}40 \text { dental implants ( } 30 \text { patients } \\
20-82 \text { years old) }\end{array}$ & 12 & $0 / 40$ SST & $\mathrm{NAv}$ & $0 / 40$ SST \\
\hline Hinze et al., 2018 [21] & Case series & $\begin{array}{l}17 \text { dental implants ( } 15 \text { patients } \\
26-66 \text { years old) }\end{array}$ & 3 & 0/17 SST & $\mathrm{NAv}$ & $\begin{array}{c}\text { SST: } 0.17 \pm 0.67 \mathrm{~mm} \\
\text { change in the gingival } \\
\text { margin } \\
\text { SST: } 8 / 15 \text { patients suffer } \\
\text { recession } \\
\text { SST: } 0.31 \pm 0.64 \mathrm{~mm} \\
\text { mesial papilla height } \\
\text { change and }-0.38 \pm \\
0.57 \text { mm distal papilla } \\
\text { height change }\end{array}$ \\
\hline Kher et al., 2018 [18] & Prospective clinical trial & $\begin{array}{l}21 \text { dental implants (17 patients } \\
26-66 \text { years old) }\end{array}$ & $12-42$ & $0 / 21$ SST & $\mathrm{NAv}$ & $\begin{array}{c}\text { SST: Pink aesthetic score: } \\
12\end{array}$ \\
\hline
\end{tabular}


Table 2. Cont.

\begin{tabular}{|c|c|c|c|c|c|c|}
\hline Author/Year & Study Type & Sample $(n)$ & $\begin{array}{c}\text { Follow-Up } \\
\text { Time (Months) }\end{array}$ & $\begin{array}{l}\text { Dental Implant } \\
\text { Failure Rate }\end{array}$ & Marginal Bone Loss & $\begin{array}{l}\text { Soft Tissue Results and } \\
\text { Pink Esthetic }\end{array}$ \\
\hline Mitsias et al., 2020 [16] & Prospective clinical trial & $\begin{array}{l}10 \text { dental implants } \\
\text { (10 patients) }\end{array}$ & 42 & 0/10 SST & NAv & $\begin{array}{c}\text { SST: } 0.19 \mathrm{~mm} \\
(0.10-0.28 \mathrm{~mm}) \\
\text { mid-facial recession }\end{array}$ \\
\hline Nguyen et al., 2019 [8] & Case series & $\begin{array}{l}4 \text { dental implants ( } 3 \text { patients } \\
62-87 \text { years old) }\end{array}$ & $24-72$ & 0/4 SST & $\begin{array}{c}0.1 \pm 0.2 \mathrm{~mm} \text { marginal } \\
\text { bone loss }\end{array}$ & $\begin{array}{l}\text { SST: No changes in soft } \\
\text { tissue dimensions }\end{array}$ \\
\hline Siormpas et al., 2014 [7] & Retrospective study & $\begin{array}{l}46 \text { dental implants (46 patients } \\
28-70 \text { years old) }\end{array}$ & $24-60$ & 0/46 SST & $\begin{array}{c}0.18 \pm 0.09 \mathrm{~mm} \text { mesial and } \\
0.21 \pm 0.09 \mathrm{~mm} \text { distal } \\
\text { marginal bone loss }\end{array}$ & NAv \\
\hline Siormpas et al., 2018 [2] & Retrospective study & $\begin{array}{l}250 \text { dental implants ( } 182 \\
\text { patients } 18-83 \text { years old) }\end{array}$ & 120 & $5 / 250$ SST & o & NAv \\
\hline Sun et al., 2020 [12] & $\mathrm{RCT}$ & 30 dental implants (30 patients & 24 & $\begin{array}{l}0 / 15 \text { CIIP } \\
0 / 15 \text { SST }\end{array}$ & NAv & $\begin{array}{c}\text { CIIP: Pink aesthetic } \\
\text { score: } 11.33 \pm 1.76 \\
\text { SST: Pink aesthetic score: } \\
12.07 \pm 1.62\end{array}$ \\
\hline Tiwari et al., 2019 [13] & $\mathrm{RCT}$ & $\begin{array}{l}16 \text { dental implants } \\
\text { (16 patients) }\end{array}$ & 12 & $\begin{array}{l}0 / 8 \text { CIIP } \\
0 / 8 \text { SST }\end{array}$ & $\begin{array}{l}\text { CIIP: } 0.188 \pm 0.013 \mathrm{~mm} \\
\text { marginal bone loss } \\
\text { SST: } 0.030 \pm 0.025 \mathrm{~mm} \\
\text { marginal bone loss }\end{array}$ & $\begin{array}{l}\text { CIIP: Labial bone } \\
\text { thickness: } \\
0.988 \pm 0.173 \mathrm{~mm} \\
\text { SST: Labial bone } \\
\text { thickness: } \\
1.145 \pm 0.277 \mathrm{~mm}\end{array}$ \\
\hline Xu et al., 2019 [14] & Prospective clinical trial & $\begin{array}{l}24 \text { dental implants } \\
\text { (24 patients) }\end{array}$ & 12 & $\begin{array}{l}0 / 12 \text { CIIP } \\
0 / 12 \text { SST }\end{array}$ & $\mathrm{NAv}$ & $\begin{array}{l}\text { SST higher PES than } \\
\text { CIIP }\end{array}$ \\
\hline
\end{tabular}

CIIP: conventional immediate dental implant placement; SST: socket-shield technique; RCT: randomized controlled trial; NAv: not available. 


\subsection{Quantitative Analysis}

\subsubsection{Failure Rate}

Sixteen studies including a total of 599 implants, with different follow-up periods ranging from 3 [21] to 120 [2] months, were combined using a random-effects model with the inverse-variance method. The rate of failure for the socket-shield technique for immediate dental implant placement in the esthetic zone was estimated to be $1.37 \%$, with a $95 \%$ confidence interval of $0.21-2.54 \%$. The meta-analysis showed no heterogeneity between the combined studies $\left(\mathrm{Q}\right.$-test $=4.98 ; p$-value $\left.=0.992 ; \mathrm{I}^{2}=0 \%\right)$. (Q test $=32.4$; $p$-value $\left.=0.070 ; \mathrm{I}^{2}=32.1 \%\right)($ Figure 2$)$.
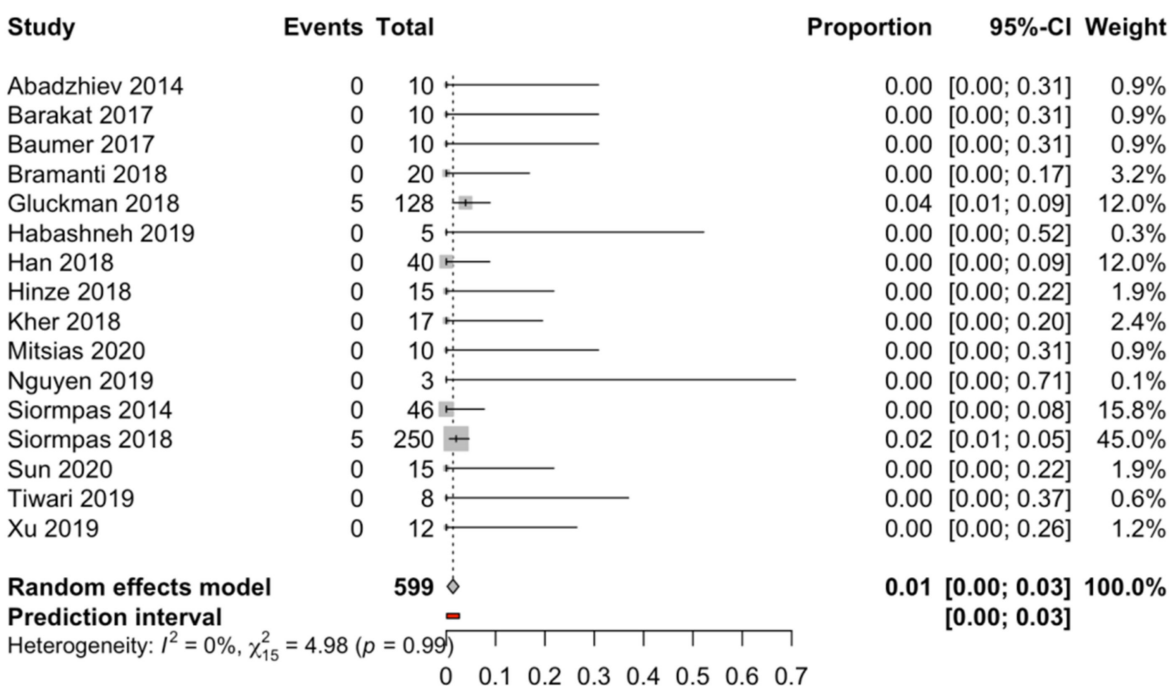

Figure 2. Forest plot of the meta-analysis of implant failure with immediate dental implant placement using the socket-shield technique.

The study follow-up time was found not to be a significant variable (beta coefficient $=$ $0.0005)$ in a meta-regression with the mixed-effects model (test of moderators $\left(R^{2}=0 \%\right.$; $\mathrm{QM}=2.23 ; p=0.134)$ ) to estimate the percentage of dental implant failure with the socketshield technique for immediate dental implant placement in the esthetic zone. The followup time does not seem to affect the prognosis after the immediate dental implant placement regardless of the placement technique.

Six studies $[4,6,12-15]$ compared the rates of dental implant failure for the socketshield technique $(n=75)$ and the conventional technique $(n=81)$; however, no statistically significant differences (odds ratio $=1.09 ; p$ value $=1 ; \mathrm{I}^{2}=0 \%$ ) were observed (Figure 3 ).

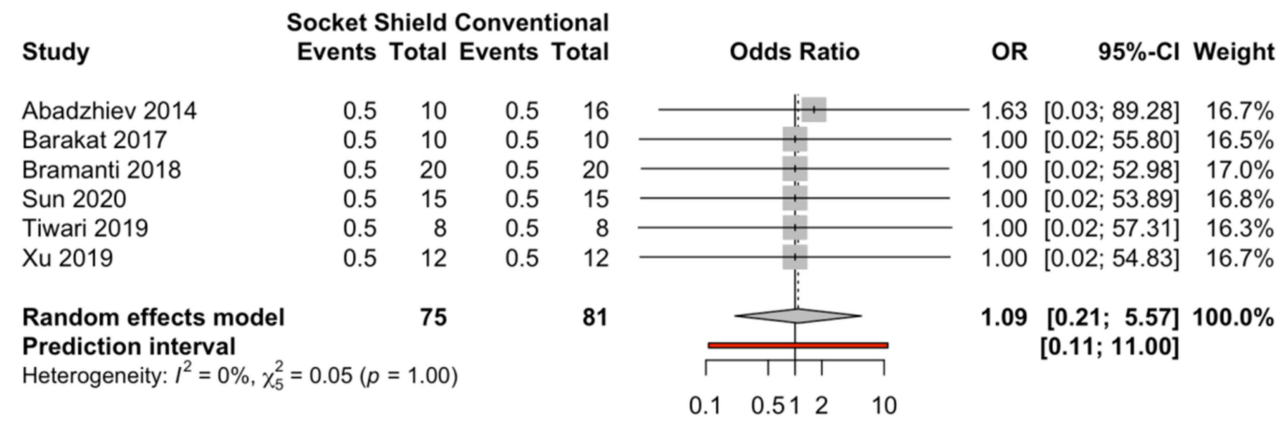

Figure 3. Forest plot of the rates of dental implant failure (odds ratio) for immediate dental implant placement using the socket-shield technique in the esthetic zone and conventional immediate dental implant placement. 


\subsubsection{Publication Bias}

Seven studies were added to the 16 studies initially combined, using the trim and fill method to obtain symmetry in the funnel plot. The dental implant failure rate for the socket-shield technique, adjusted using the inverse-variance random-effects model, was $1.78 \%$ (95\% CI, 0.73-2.83), showing no difference with respect to the initial 1.37 (Figure 4).
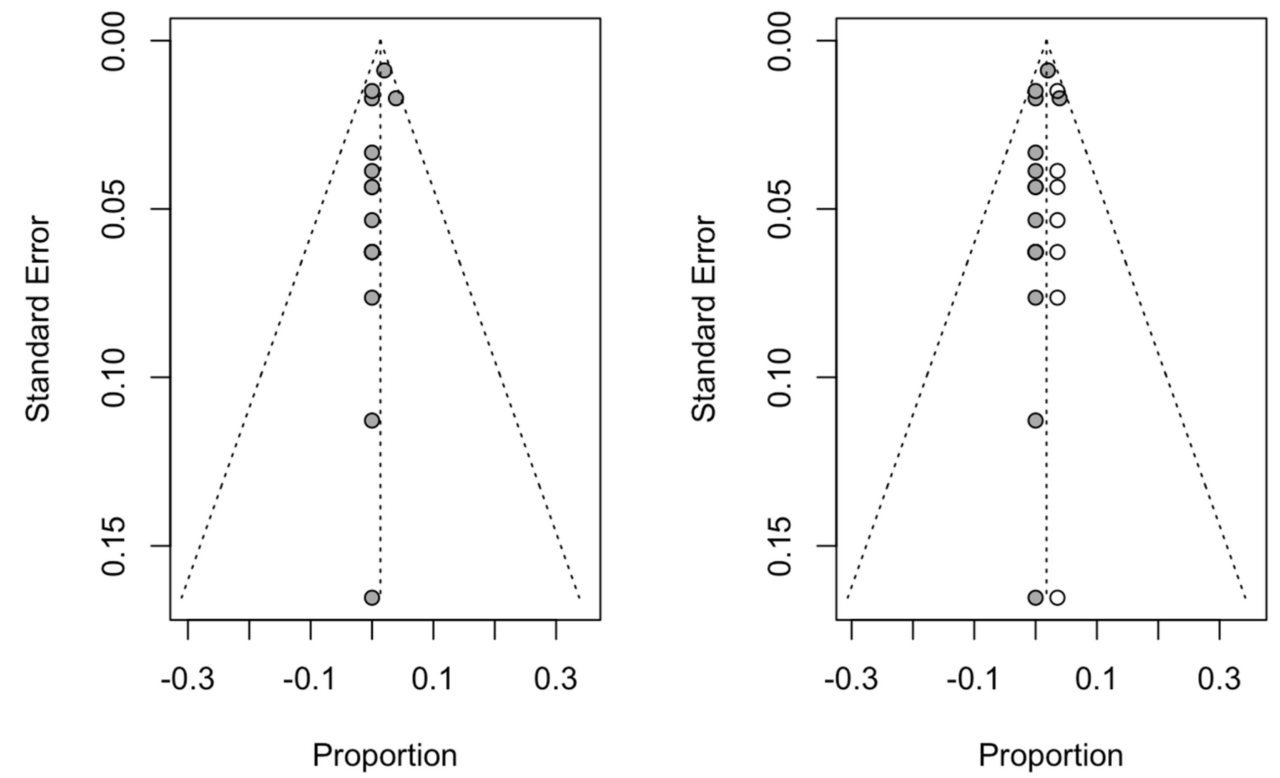

Figure 4. Initial funnel plot and plot after trim and fill adjustment of the dental implant failure of the socket-shield technique for dental immediate implant placement in the esthetic zone.

\subsubsection{Marginal Bone Loss}

Three studies compared the marginal bone loss for the conventional immediate dental implant placement $(n=58)$ and the socket-shield technique $(n=58)$. The estimated mean difference was $-0.5 \mathrm{~mm}(95 \% \mathrm{CI},-0.82$ to -0.18$)$ and statistically significant $(p<0.01)$, and the heterogeneity was high according to the meta-analysis $\left(\mathrm{I}^{2}=99 \%\right.$ ) (Figure 5 .

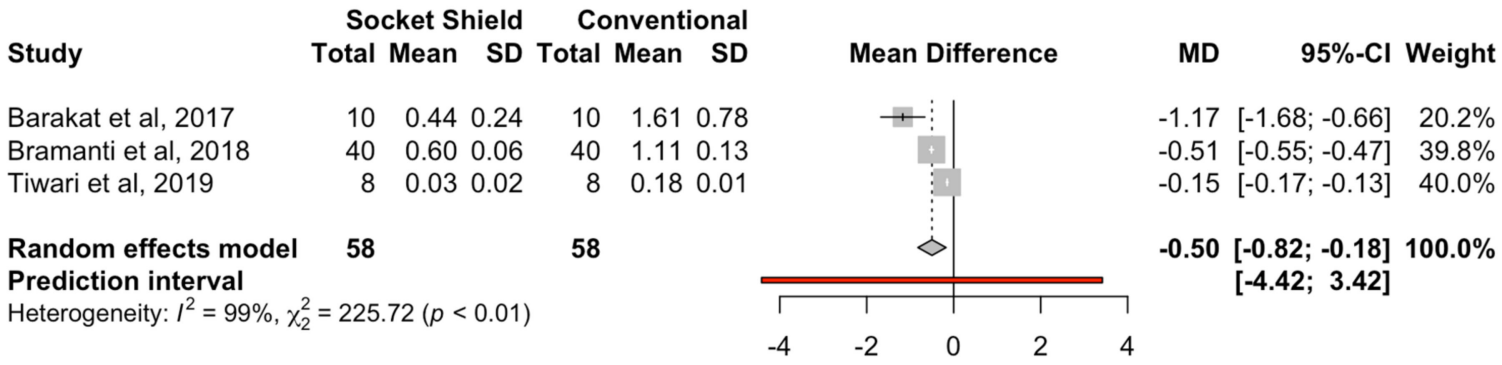

Figure 5. Forest plot of the mean difference in marginal bone loss $(\mathrm{mm})$ between immediate dental implant placement using the socket-shield technique and conventional placement technique.

The study follow-up time was not found to be a significant variable (beta coefficient $=0.0094)$ in a meta-regression with the mixed-effects model $\left(\mathrm{R}^{2}=0 \%\right.$; test of moderators $\mathrm{QM}=0.090 ; p=0.764$ ) to estimate the mean difference in bone loss between the two techniques.

\subsubsection{Publication Bias}

Two studies were added to the three studies initially combined, using the trim and fill method to obtain symmetry in the funnel plot. The estimated mean difference in marginal bone loss, adjusted using the inverse-variance random-effects model, was $-0.15 \mathrm{~mm}(95 \%$ 
$\mathrm{CI},-0.43$ to 0.13 ), showing a significant difference with respect to the initial $-0.50 \mathrm{~mm}$ (Figure 6).
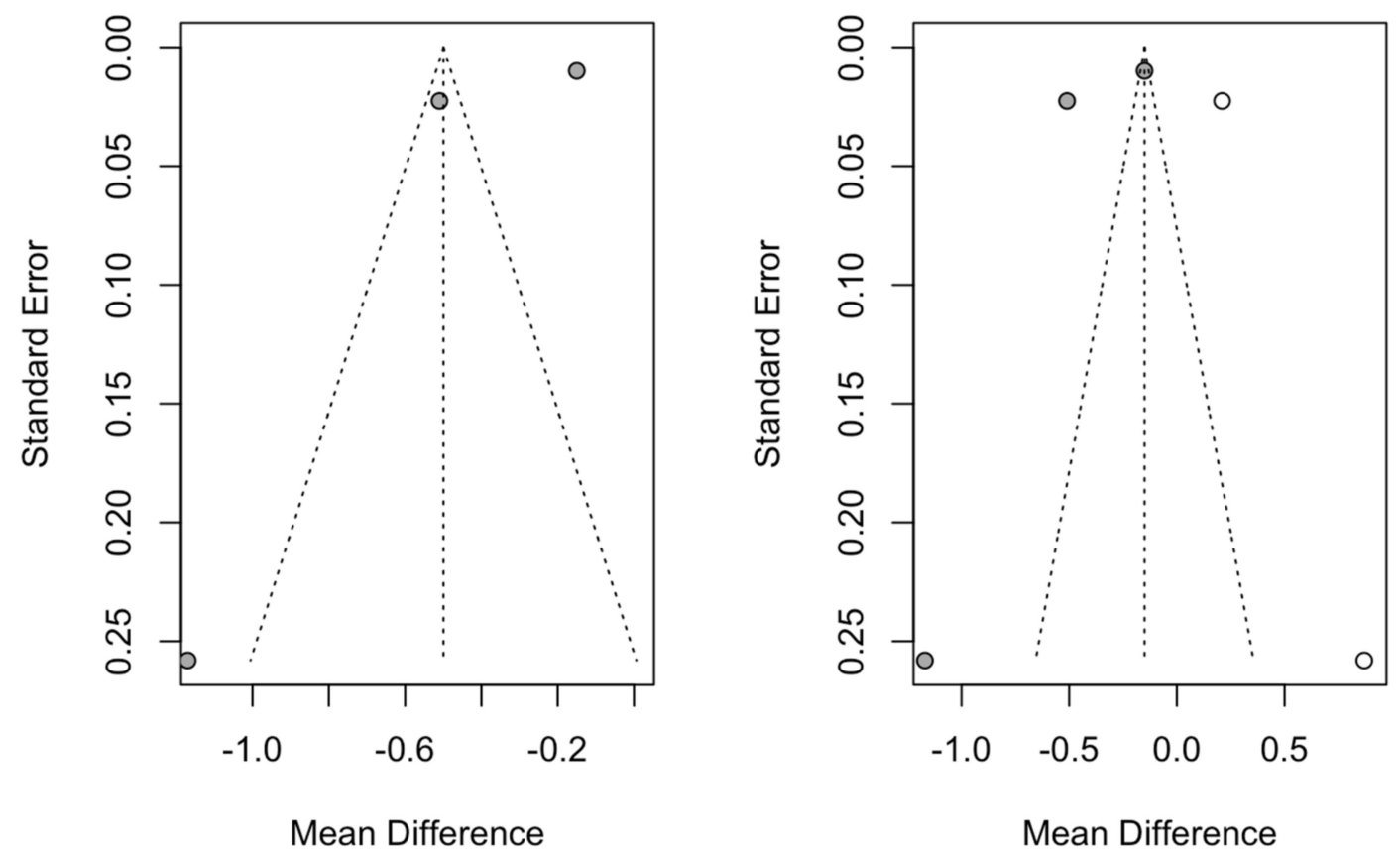

Figure 6. Initial funnel plot and plot after trim and fill adjustment of the mean difference in bone loss (mm) for the immediate dental implant placement in the esthetic zone using the socket-shield technique.

\subsubsection{Pink Esthetic Score}

Scores from three studies with pink esthetic score (PES) measurements taken at different points during the follow-up have been included. The mean PES obtained by combining the studies with the random-effects model (inverse variance) was 12.27 (range, 12.12-12.41). Heterogeneity was not detected $\left(\mathrm{Q}\right.$ test $=4.47 ; p$ value $=0.61 ; \mathrm{I}^{2}=0 \%$ (Figure 7).

\section{Study}

Bramanti 2018a

Bramanti 2018b

Bramanti 2018c

Baurner 2018

Sun 2020 a

Sun $2020 b$

Sun $2020 c$

\section{Random effects model \\ Prediction interval}

Heterogeneity: $I^{2}=0 \%, \chi_{6}^{2}=4.47(p=0.61)$

\section{Mean}

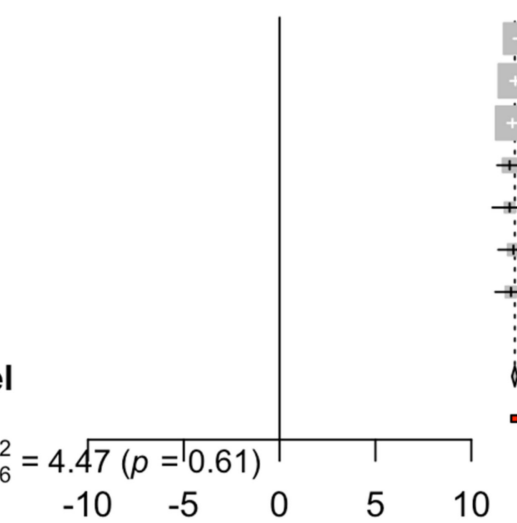

MRAW

95\%-Cl Weight

Figure 7. Forest plot of the mean PES of immediate dental implant placement using the socket-shield technique in the esthetic zone.

Two studies with three measurements throughout the follow-up period (ranging from 3 to 40 months) compared the PESs for the conventional immediate dental implant placement $(n=55)$ and the socket-shield technique $(n=55)$. The meta-analysis (randomeffects model combined with the inverse-variance method) estimated a mean difference 
between the techniques of 1.15 (95\% CI, 0.73-1.58). There was slight heterogeneity between the studies $\left(\mathrm{Q}\right.$ test $=8.88 ; p$-value $=0.11 ; \mathrm{I}^{2}=44 \%$ ). The PES for the socket-shield technique showed a difference of 1.15 points with respect to that for the conventional technique (Figure 8).

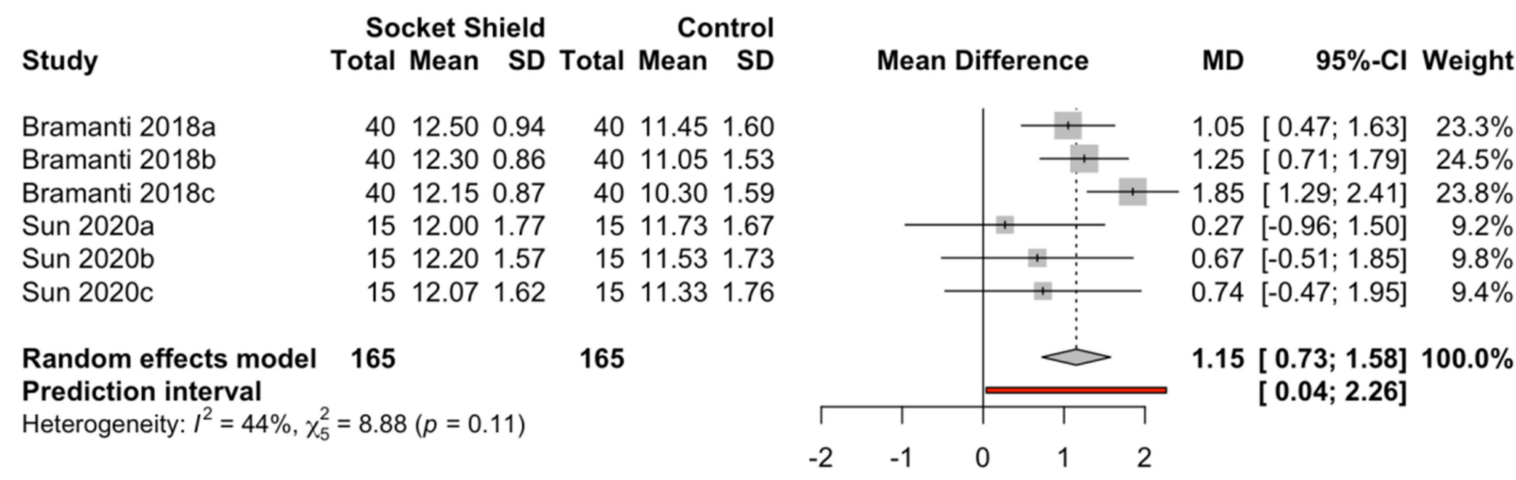

Figure 8. Forest plot of the mean difference in PES between immediate dental implant placement using the socket-shield technique and conventional technique in the esthetic zone.

The follow-up time was found to be a significant variable (beta coefficient $=0.023$ ) in a meta-regression with the mixed-effects model $\left(\mathrm{R}^{2}=85.6 \%\right.$; $\left.\mathrm{QM}=3.82 ; p=0.049\right)$ for estimating the mean difference in PES between the conventional immediate dental implant placement and placement using the socket-shield technique. The difference in PES increased by 0.02 points / month for the socket-shield technique with respect to the conventional method (Figure 9).

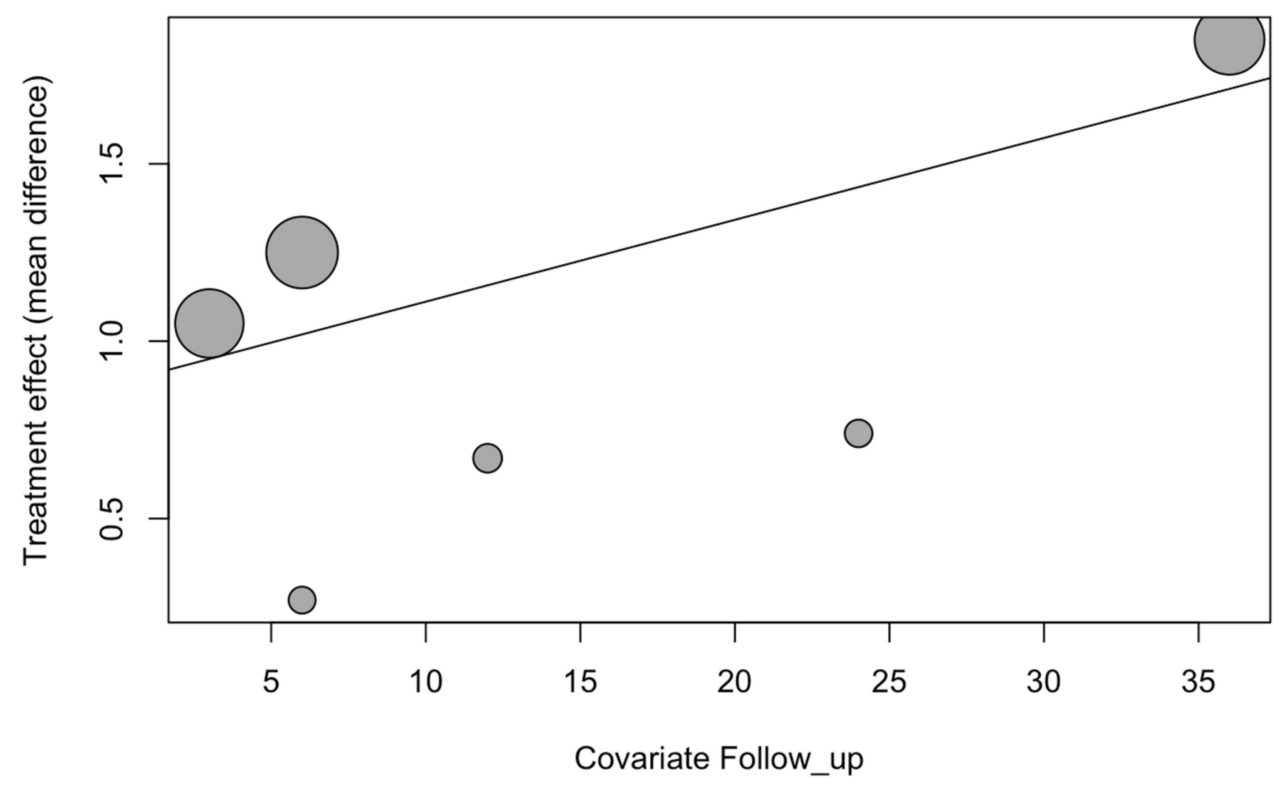

Figure 9. Bubble plot of follow-up time as a covariate of the PES for the immediate dental implant placement using the socket-shield technique in the esthetic zone.

\subsubsection{Publication Bias}

Three studies were added to the seven studies initially combined, using the trim and fill method to obtain symmetry in the funnel plot. The estimate of the mean PES adjusted by the inverse random-effects model of the variance was 12.30 (95\% CI, 12.16-12.44), not showing a difference with respect to the initial 12.27 (Figure 10). 

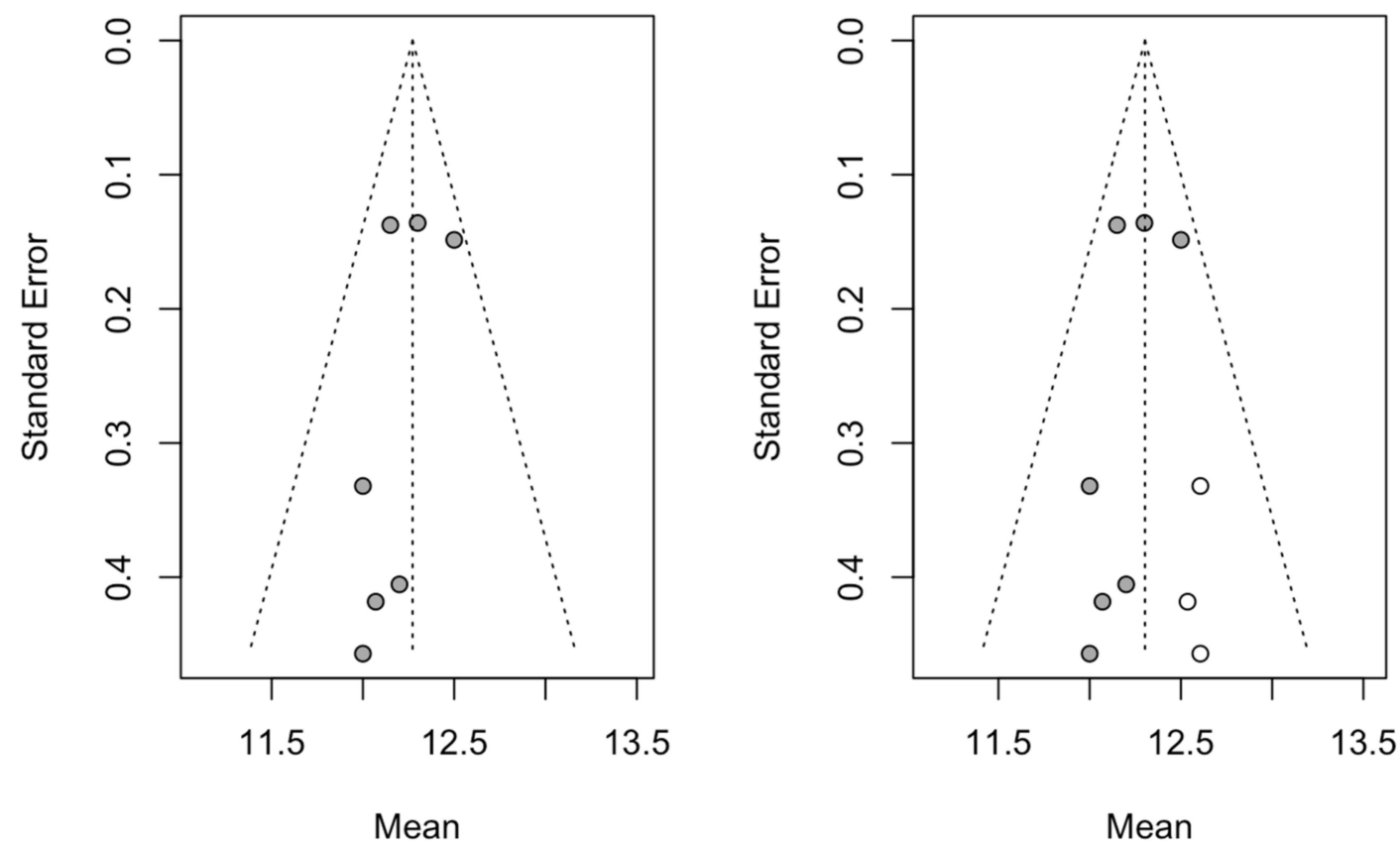

Figure 10. Initial funnel plot and plot after trim and fill adjustment of the mean difference in PES for the immediate dental implant placement using the socket-shield technique in the esthetic zone.

\section{Discussion}

This systematic review with meta-analysis was centered on the dental implant failure rate, marginal bone loss, and pink esthetic for a single immediate dental implant in the esthetic zone through the conventional or socket-shield technique. The results obtained in the present study refute the null hypothesis $\left(\mathrm{H}_{0}\right)$ stating that there was no statistically significant difference in the marginal bone loss and pink esthetic between the socket-shield and conventional techniques for immediate dental implant placement in the esthetic zone. However, there was no statistically significant difference in the dental implant failure rate between the techniques.

A mean dental implant failure rate of $1.37 \%$ (95\% CI: $0.21-2.54 \%$ ) was found, in this systematic review with meta-analysis, for the socket-shield technique; moreover, the studies with the highest sample sizes and longest follow-ups $[2,20]$ showed high rates of dental implant survival. Gluckman et al. analyzed 128 immediate dental implants performed in the esthetic zone with the socket-shield technique with at least four years of follow-up and reported a dental implant survival rate of 96.1\% [20], and Siormpas et al. included 250 immediate dental implants performed with the socket-shield technique with a follow-up of 10 years and reported a dental implant survival rate of $98 \%$; however, some eventual complications such as infections of the root membrane, internal and external exposures, and migration of the dental implant were reported [2].

Hürzeler et al. established that the main objective of the socket-shield technique for immediate dental implant placement is preserving the buccal bone plate, which could influence the esthetic results [21]; therefore, most of the dental implants in the selected articles were placed in the anterior maxillary. However, this location usually presents a narrow buccal cortical plate, which increases the risk of marginal bone resorption after tooth extraction [22]. Moreover, Tsigarida et al. reported that most of the buccal bone walls in anterior maxillary teeth are narrower than $1 \mathrm{~mm}$ at the coronal third, and buccal bone walls wider than $2 \mathrm{~mm}$ were only measured in the middle third of canine and premolar teeth and in the apical third of every tooth [23]. However, the thickness of the marginal bone crest around teeth can remain stable due to the vascular supply from the periodontal vessels [24], although a thin marginal bone crest around dental implants can be reabsorbed, leading to the exposure of the rough surface of the dental implant [24] because the fasciculated bone 
of the internal portion of the alveolus is usually reabsorbed after tooth extraction without the adjacent periodontal tissues [24], leading to an unaesthetic effect due to the retraction of the buccal mucosa after buccal bone resorption [4]. Therefore, the maintenance of the periodontal tissues is still a concern, which could be solved by the preservation of the buccal fragment of the dental root [6]. In addition, Mitsias et al. reported an absence of buccal bone loss at 5 years follow-up using the socket-shield technique for dental immediate implant placement in the esthetic zone [25], and Baümer et al. highlighted the biological effect of the socket-shield technique [26]. In addition, some authors have reported the influence of grafting materials for filling the space between the root fragment and the dental implant. Gluckman et al. reported that the space between the implant and the buccal portion of the root fragment should always be filled with graft material [20]. Habashneh et al. and Bramanti et al. recommend filling the space with a heterologous graft material to improve the healing process and to further reduce bone resorption and facilitate bone-implant contact $[4,22]$. However, Siormpas et al. suggested that it is not necessary to graft the space between the residual buccal root fragment and the dental implant [7]. This concept is supported by recent histological data showing that, without the use of biomaterials, new bone grows in the space between the dentin fragment and the dental implant [4].

Blaschke and Schwass published a systematic review without meta-analysis and highlighted promising outcomes for the socket-shield technique; however, they also mentioned the limited data available related to well-designed prospective randomized controlled studies, which tend not to report the long-term outcomes for the socket-shield technique [27]. Ogawa et al. also published a systematic review without meta-analysis and reported $90.5 \%$ implant survival and a low failure rate [28]; however, the present study only showed $1.37 \%$ implant failure.

The maintenance of the marginal bone crest associated with the socket-shield technique for dental immediate implant placement could influence the high PES observed. This esthetic visual index was selected out of eight esthetic evaluation indices, as it was deemed to be the most reliable and valid; PES is therefore often used to analyze the pink esthetic around dental immediate implants [29].

The PES measurement index takes into account the mesial and distal papilla insertion level, the soft tissue level and contour, the alveolar process deficiency and the soft tissue color and texture. The high mean PESs (12.27 (range, 12.12-12.41)) shown in this systematic review with meta-analysis could be attributable to the few volumetric alterations of the soft tissues and, hence, to the maintained marginal bone crest surrounding the immediate dental implants with the socket-shield technique. Moreover, Baümer et al. reported minimal changes associated with the gingival contour, few recessions observed at both the immediate dental implants and the neighboring teeth, and little marginal bone loss, showing compatibility with peri-implant health [19]. Additionally, Hinze et al. observed volumetric changes minor to $0.5 \mathrm{~mm}$ in all cases with a follow-up of 3 months [21].

From the literature reviewed, the socket-shield technique for immediate dental implant placement in the esthetic zone seems to be a successful and minimally invasive technique, although more long-term and better-designed studies are needed. As for the limitations of this systematic review with meta-analysis, there was a risk of articles related to the selection criteria not being found, although this risk was reduced by searching in 4 databases. In addition, most of studies presented poor methodological quality with scores lower than 3 on the Jadad scale.

\section{Conclusions}

Within the limitations of this systematic review with meta-analysis, the rate of dental implant failure did not differ between the socket-shield technique and conventional technique for immediate implant placement in the esthetic zone. However, lower marginal bone loss and higher pink esthetic scores were found for the socket-shield technique.

Author Contributions: Conceptualization, P.V.B., Á.Z.-M., and J.M.M.-C., design, R.R.; data acquisition, E.C.M.; formal analysis, L.S.H.M. and S.d.l.V.B.; all statistical analyses, Á.Z.-M. and 
J.M.M.-C.; review and editing, S.H.M. All authors have read and agreed to the published version of the manuscript.

Funding: This research received no external funding.

Institutional Review Board Statement: Not applicable.

Informed Consent Statement: Not applicable.

Data Availability Statement: Data available on request due to restrictions, e.g., privacy and ethical.

Conflicts of Interest: The authors declare no conflict of interest.

$\begin{array}{ll}\text { Abbreviations } \\ \text { PRISMA } & \text { Preferred Reporting Items for Systematic Reviews and Meta-Analyses } \\ \text { CI } & \text { Confidence Interval } \\ \text { PES } & \text { Pink esthetic score } \\ \text { OR } & \text { Odds ratio } \\ \text { NA } & \text { Not applicable } \\ \text { NAv } & \text { Not available } \\ \text { CIIP } & \text { Conventional immediate dental implant placement } \\ \text { SST } & \text { Socket-shield technique } \\ \text { RCT } & \text { Randomized controlled trial }\end{array}$

\section{References}

1. Abd-Elrahman, A.; Shaheen, M.; Askar, N.; Atef, M. Socket shield technique vs conventional immediate implant placement with immediate temporization. Randomized clinical trial. Clin. Implant Dent. Relat. Res. 2020, 22, 602-611. [CrossRef]

2. Siormpas, K.D.; Mitsias, M.E.; Kotsakis, G.A.; Tawil, I.; Pikos, M.A.; Mangano, F.G. The Root Membrane Technique: A Retrospective Clinical Study with up to 10 Years of Follow-Up. Implant Dent. 2018, 27, 564-574. [CrossRef]

3. Calvo-Guirado, J.L.; Troiano, M.; López-López, P.J.; Ramírez-Fernandez, M.P.; de Val Sanchze, J.E.; Marin, J.M.; Gehrke, S.A. Different configuration of socket shield technique in peri-implant bone preservation: An experimental study in dog mandible. Ann. Anat. 2016, 208, 109-115. [CrossRef]

4. Bramanti, E.; Norcia, A.; Cicciù, M.; Matacena, G.; Cervino, G.; Troiano, G.; Zhurakivska, K.; Laino, L. Postextraction Dental Implant in the Aesthetic Zone, Socket Shield Technique Versus Conventional Protocol. J. Craniofac. Surg. 2018, 29, $1037-1041$. [CrossRef] [PubMed]

5. Han, C.H.; Park, K.B.; Mangano, F.G. The Modified Socket Shield Technique. J. Craniofac. Surg. 2018, 29, 2247-2254. [CrossRef]

6. Barakat, D.A.; Hassan, R.S.; Eldibany, R.M. Evaluation of the shocket shield technique for immediate implantation. Alex. Dent. J. 2017, 42, 155-161. [CrossRef]

7. Giudice, A.; Bennardo, F.; Antonelli, A.; Barone, S.; Wagner, F.; Fortunato, L.; Traxler, H. Influence of clinician's skill on primary implant stability with conventional and piezoelectric preparation techniques: An ex-vivo study. J. Biol. Regul. Homeost. Agents 2020, 34, 739-745. [PubMed]

8. Siormpas, K.D.; Mitsias, M.E.; Kontsiotou-Siormpa, E.; Garber, D.; Kotsakis, G.A. Immediate implant placement in the esthetic zone utilizing the "root-membrane" technique: Clinical results up to 5 years postloading. Int. J. Oral Maxillofac. Implants 2014, 29, 1397-1405. [CrossRef]

9. Nguyen, V.G.; Flanagan, D.; Syrbu, J.; Nguyen, T.T. Socket Shield Technique Used in Conjunction with Immediate Implant Placement in the Anterior Maxilla: A Case Series. Clin. Adv. Periodontics 2020, 10, 64-68. [CrossRef] [PubMed]

10. Fürhauser, R.; Florescu, D.; Benesch, T.; Haas, R.; Mailath, G.; Watzek, G. Evaluation of soft tissue around single-tooth implant crowns: The pink esthetic score. Clin. Oral Implants Res. 2005, 16, 639-644. [CrossRef]

11. Liberati, A.; Banzi, R.; Moja, L. Measuring the impact of evidence: The Cochrane systematic review of organized stroke care. Intern. Emerg. Med. 2009, 4, 507-510.

12. Jadad, A.R.; Moore, R.A.; Carroll, D.; Jenkinson, C.; Reynolds, D.J.M.; Gavaghan, D.J.; McQuay, H.J. Assessing the quality of reports of randomized clinical trials: Is blinding necessary? Control. Clin. Trials 1996, 17, 1-12. [CrossRef]

13. Sun, C.; Zhao, J.; Liu, Z.; Tan, L.; Huang, Y.; Zhao, L.; Tao, H. Comparing conventional flap-less immediate implantation and socket-shield technique for esthetic and clinical outcomes: A randomized clinical study. Clin. Oral Implants Res. 2020, 31, 181-191. [CrossRef]

14. Tiwari, S.; Bedi, R.S.; Wadhwani, P.; Aurora, J.K.; Chauhan, H. Comparison of Immediate Implant Placement Following Extraction with and without Socket-Shield Technique in Esthetic Region. J. Maxillofac. Oral Surg. 2020, 19, 552-560. [CrossRef]

15. Xu, Y.M.; Huang, H.; Wang, L.; Wu, Q.Q.; Fu, G.; Li, J. Comparison of clinical effects of a modified socket shield technique and the conventional immediate implant placement. Hua Xi Kou Qiang Yi Xue Za Zhi 2019, 37, 490-495. 
16. Kher, U.; Tunkiwala, A.; Shanbag, S. A graftless socket- shield technique for immediate implant placement in the esthetic zone. Clin. Oral Implants Res. 2018, 29, 451. [CrossRef]

17. Bäumer, D.; Zuhr, O.; Rebele, S.; Hürzeler, M. Socket Shield Technique for immediate implant placement-Clinical, radiographic and volumetric data after 5 years. Clin. Oral Implants Res. 2017, 28, 1450-1458. [CrossRef] [PubMed]

18. Gluckman, H.; Salama, M.; Du Toit, J. A retrospective evaluation of 128 socket-shield cases in the esthetic zone and posterior sites: Partial extraction therapy with up to 4 years follow-up. Clin. Implant Dent. Relat. Res. 2018, 20, 122-129. [CrossRef] [PubMed]

19. Hinze, M.; Janousch, R.; Goldhahn, S.; Schlee, M. Volumetric alterations around single-tooth implants using the socket-shield technique: Preliminary results of a prospective case series. Int. J. Esthet Dent. 2018, 13, 146-170. [PubMed]

20. Habashneh, R.A.; Walid, M.A.; Abualteen, T.; Abukar, M. Socket-shield Technique and Immediate Implant Placement for Ridge Preservation: Case Report Series with 1-year Follow-up. J. Contemp. Dent. Pract. 2019, 20, 1108-1117. [CrossRef] [PubMed]

21. Hürzeler, M.B.; Zuhr, O.; Schupbach, P.; Rebele, S.F.; Emmanouilidis, N.; Fickl, S. The socket-shield technique: A proof-of-principle report. J. Clin. Periodontol. 2010, 37, 855-862. [CrossRef]

22. Araújo, M.G.; Silva, C.O.; Misawa, M.; Sukekava, F. Alveolar socket healing: What can we learn? Periodontol. 2000 2015, 68, 122-134. [CrossRef]

23. Tsigarida, A.; Toscano, J.; de Brito Bezerra, B.; Geminiani, A.; Barmak, A.B.; Caton, J.; Papaspyridakos, P.; Chochlidakis, K. Buccal bone thickness of maxillary anterior teeth: A systematic review and meta-analysis. J. Clin. Periodontol. 2020, 47, 1326-1343. [CrossRef]

24. Monje, A.; Chappuis, V.; Monje, F.; Muñoz, F.; Wang, H.L.; Urban, I.A.; Buser, D. The Critical Peri-implant Buccal Bone Wall Thickness Revisited: An Experimental Study in the Beagle Dog. Int. J. Oral Maxillofac. Implants 2019, 34, 1328-1336. [CrossRef]

25. Mitsias, M.E.; Siormpas, K.D.; Kotsakis, G.A.; Ganz, S.D.; Mangano, C.; Iezzi, G. The Root Membrane Technique: Human Histologic Evidence after Five Years of Function. Biomed. Res. Int. 2017, 2017, 7269467. [CrossRef] [PubMed]

26. Bäumer, D.; Zuhr, O.; Rebele, S.; Schneider, D.; Schupbach, P.; Hürzeler, M. The socket-shield technique: First histological, clinical, and volumetrical observations after separation of the buccal tooth segment-A pilot study. Clin. Implant Dent. Relat. Res. 2015, 17, 71-82. [CrossRef] [PubMed]

27. Blaschke, C.; Schwass, D.R. The socket-shield technique: A critical literature review. Int. J. Implant Dent. 2020, 6, 52. [CrossRef] [PubMed]

28. Ogawa, T.; Sitalaksmi, R.M.; Miyashita, M.; Maekawa, K.; Ryu, M.; Kimura-Ono, A.; Suganuma, T.; Kikutani, T.; Fujisawa, M.; Tamaki, K.; et al. Effectiveness of the Socket Shield Technique in Dental Implant: A Systematic Review. J. Prosthodont. Res. 2021. [CrossRef] [PubMed]

29. Hof, M.; Umar, N.; Budas, N.; Seemann, R.; Pommer, B.; Zechner, W. Evaluation of implant esthetics using eight objective indices-Comparative analysis of reliability and validity. Clin. Oral Implants Res. 2018, 29, 697-706. [CrossRef] 